\title{
Hubungan antara Faktor Stres dan Siklus Menstruasi pada Mahasiswi Fakultas Kedokteran Universitas Sumatera Utara
}

\author{
Bahagia W.M. Nainggolan*, Khairani Sukatendel \\ Departemen Obstetri dan Ginekologi, Fakultas Kedokteran, Universitas Sumatera Utara, Medan \\ *Correspondence: bahagianainggolan@gmail.com
}

\begin{abstract}
ABSTRAK
Latar Belakang: Stresor adalah suatu hal yang dapat diidentifikasikan sebagai penyebab timbulnya stres. Stres dapat memberikan dampak negatif dalam aspek kognitif, fisiologi, dan perilaku. Salah satu dampak dari stres yang dapat terjadi adalah gangguan siklus menstruasi. Tujuan: Mengetahui pengaruh faktor stres terhadap siklus menstruasi pada mahasiswi Fakultas Kedokteran Universitas Sumatera Utara. Metode: Metode yang digunakan dalam penelitian ini adalah metode analitik dengan desain cross-sectional. Penelitian dilakukan pada mahasiswi Fakultas Kedokteran Universitas Sumatera Utara. Pengumpulan atau pengambilan data untuk diteliti dilakukan menggunakan kuesioner Medical Student Stressor Questionnaire (MSSQ) dan data siklus menstruasi yang diberikan kepada responden dengan syarat memenuhi kriteria inklusi maupun kriteria eksklusi yang telah ditetapkan serta menggunakan consecutive sampling sebagai metode yang digunakan. Hasil: Dari 80 responden, didapatkan hasil uji Kendall's Correlation $(p>0.05)$ untuk setiap hubungan faktor stres dengan siklus menstruasi yang berarti tidak ada hubungan yang signifikan antara faktor stres dengan siklus menstruasi. Kesimpulan: Dari penelitian ini disimpulkan bahwa tidak terdapat pengaruh yang signifikan antara faktor stres dengan siklus menstruasi pada mahasiswi Fakultas Kedokteran Universitas Sumatera Utara.
\end{abstract}

Kata Kunci: siklus menstruasi, stres, stresor

\section{ABSTRACT}

Background: Stressor is defined as the agent inducing the response of stress. Stress can give a negative impact on cognitives, physiological, and behavioral aspects. One of the effects of stress that can be occur is menstrual cycle disorder. Objectives: To know how is the relationship between stressors and menstrual cycle on medical students in Faculty of Medicine, University of Sumatera Utara. Methods: This study used an analytic method with a cross sectional design. The study population was medical students in Faculty of Medicine, University of Sumatera Utara. The data was collected by filling The MSSQ questionnaire and the menstrual data that had been given to respondents if only the inclusion and exclusion criteria was met and used consecutive sampling for the methods. Results: From 80 respondents, the results obtained by Kendall's Correlation $p>0,05$ for correlation each stressors with menstrual cycle which means that there is no significant relationship between stressors and menstrual cycle. Conclusion: From this study it can be concluded that there is no significant relationship between stressors and menstrual cycle on medical students in Faculty of Medicine, USU.

Keywords: menstrual cycle, stress, stressor

Received [8 Feb 2021] | Revised [25 Jul 2021] | Accepted [20 Aug 2021]

\section{PENDAHULUAN}

Menstruasi adalah peristiwa keluarnya darah dari rahim melalui vagina dan keluar dari tubuh seorang wanita setiap bulan selama masa usia subur dikarenakan meluruhnya lapisan dinding rahim yang banyak mengandung pembuluh darah 
(endometrium), pada saat sel telur tidak dibuahi. ${ }^{[1]}$ Pola siklus menstruasi ini dipengaruhi oleh usia, tingkat stres, obatobatan dan alat kontrasepsi dalam rahim, kehamilan dan gangguan kehamilan serta kelainan genetik ${ }^{[2]}$

Stres merupakan suatu respon fisiologis, psikologis dan perilaku dari manusia yang mencoba untuk mengadaptasi dan mengatur baik tekanan internal dan eksternal (stresor). ${ }^{[3]}$ Mahasiswa selaku individu akademik dalam kegiatannya juga tidak terlepas dari stres. Penyebab stres pada mahasiswa dapat berasal dari kehidupan akademik terutama dari tuntutan eksternal maupun tuntutan dari harapan individu itu sendiri. $^{[4]}$

Pada saat stres, tubuh seseorang akan mengeluarkan adrenalin sebagai bentuk pertahanan. Stres atau emosi merupakan bagian dari sistem umpan balik siklus hormon di dalam tubuh manusia. Peningkatan kadar kortisol dalam darah dapat mempengaruhi menstruasi bahkan dapat memicu adanya gangguan menstruasi pada wanita. ${ }^{[5]}$

Berdasarkan hasil penelitian yang dilakukan di Universitas Sumatera Utara menunjukkan bahwa tidak ditemukan adanya pengaruh yang signifikan antara tingkat stres dengan menstruasi pada mahasiswi Fakultas Kedokteran Universitas Sumatera Utara. ${ }^{[6]}$ Hal ini berbeda dengan hasil penelitian di Fakultas Kedokteran Universitas Sam Ratulangi Manado yang menunjukkan bahwa ditemukan hubungan antara tingkat stres dengan siklus haid pada mahasiswi. ${ }^{[7]}$

Berdasarkan hal tersebut dan jurnaljurnal yang diperoleh penulis, terdapat penelitian yang menyatakan adanya hubungan antara stres dengan menstruasi dan ada pula yang menyatakan bahwa tidak adanya hubungan yang signifikan antara stres dengan menstruasi pada mahasiswi Fakultas Kedokteran, tetapi penulis tidak menemukan adanya jurnaljurnal yang membahas hubungan antara faktor stres dengan siklus menstruasi pada mahasiswi Fakultas Kedokteran.

Penulis memilih faktor stres sebagai bahan penelitian karena tidak adanya jurnal-jurnal yang menjelaskan hubungan faktor stres dengan siklus menstruasi khususnya pada mahasiswi kedokteran. Maka dari itu penulis melakukan penelitian dengan tujuan untuk mengetahui pengaruh faktor stres terhadap menstruasi pada mahasiswi Fakultas Kedokteran Universitas Sumatera Utara.

\section{METODE}

Penelitian ini menggunakan metode analitik observasional dengan desain penelitian cross sectional. Penelitian ini dilakukan di Fakultas Kedokteran Universitas Sumatera Utara dengan jumlah populasi 400 orang.

Teknik pengambilan sampel pada penelitian ini dilakukan dengan cara consecutive sampling. Sampel yang dibutuhkan pada penelitian ini didapatkan menggunakan rumus Slovin, yaitu sebanyak 80 orang. Kriteria inklusi subjek: mahasiswi aktif Fakultas Kedokteran Universitas Sumatera Utara angkatan 2017-2019, responden sehat, belum menikah dan/atau hamil, tidak menggunakan obat $\mathrm{KB}$, tidak memiliki penyakit dan/atau gangguan hormon/ginekologi, dan sudah mengalami menstruasi, serta menandatangani informed consent. Kriteria eksklusi subjek: mahasiswi memiliki Body Mass Index $(\mathrm{BMI})>25$ dengan durasi tidur $<5$ jam per hari dan salah satu pertanyaan kuesioner tidak dijawab. Peneliti mengeksklusikan Body Mass Index (BMI) >25 dengan durasi tidur $<5$ jam karena beberapa penelitian menunjukkan adanya hubungan BMI dan tidur yang teratur dengan siklus menstruasi.

Pengumpulan data dalam penelitian ini dilakukan dengan menggunakan wawancara secara online dengan menggunakan kuesioner siklus menstruasi dan Medical Student Stressor 
Questionnaire (MSSQ). Kuesioner siklus menstruasi digunakan untuk mengetahui siklus menstruasi pada responden dengan kriteria normal (siklus $21-35$ hari) dan tidak normal (siklus <21 hari, siklus >35 hari, dan amenore). MSSQ merupakan kuesioner yang digunakan untuk mengetahui tingkatan stres dan faktor stres pada mahasiswa kedokteran yang terdiri dari 40 pertanyaan dengan 6 domain faktor stres, yaitu Academic Related Stressors (ARS), Interpersonal \& Intrapersonal Related Stressors (IRS), Teaching and Learning Related Stressors (TLRS), Social Related Stressors (SRS), Drive \& Desire Related Stressors (DRS), dan Group Activities Related Stressors (GARS). Setiap pertanyaan diberikan rentang skor 0 sampai 4 dengan interpretasi skor ringan $(0-1)$, sedang $(1-2)$, berat $(2-3)$, dan sangat berat $(3-4)$. Data dianalisis secara statistik menggunakan uji korelasi Kendall's tau-C Correlation menggunakan program Statistic Package for Social Science (SPSS).

\section{HASIL}

Penelitian ini dilakukan terhadap 80 mahasiswi aktif Fakultas Kedokteran Universitas Sumatera Utara yang dilakukan mulai tanggal 9 Oktober 2020 24 November 2020.

Karakteristik Responden

Tabel 1. Karakteristik Responden

\begin{tabular}{ccc}
\hline Karakteristik & Frekuensi & $\begin{array}{c}\text { Persentase } \\
(\%)\end{array}$ \\
\hline Umur & & \\
\hline 17 & 2 & 2,5 \\
18 & 4 & 5,0 \\
19 & 14 & 17,5 \\
20 & 25 & 31,25 \\
21 & 27 & 33,75 \\
22 & 8 & 10,0 \\
\hline Siklus Menstruasi & & \\
\hline Normal & 69 & 86,25 \\
Tidak Normal & 11 & 13,75 \\
\hline Tingkat Stres & & \\
\hline Ringan & 10 & 12,5 \\
Sedang & 25 & 31,25 \\
Berat & 38 & 47,5 \\
Sangat Berat & 7 & 8,75 \\
\hline
\end{tabular}

Tabel 1 menunjukkan karakteristik responden berdasarkan umur, IMT, siklus menstruasi, dan tingkatan stres. Responden sebagian besar berusia 21 tahun, mengalami siklus menstruasi normal, dan tingkat stres berat.

\section{Gambaran Tingkat Stres berdasarkan Stressor}

Tabel 2. Gambaran Tingkat Stres berdasarkan Stresor

\begin{tabular}{ccccc}
\hline $\begin{array}{c}\text { Faktor } \\
\text { Stres }\end{array}$ & \multicolumn{4}{c}{ Tingkat Stres } \\
\cline { 2 - 5 } & $\begin{array}{c}\text { Ringan } \\
(\%)\end{array}$ & $\begin{array}{c}\text { Sedang } \\
(\boldsymbol{\%})\end{array}$ & $\begin{array}{c}\text { Berat } \\
(\%)\end{array}$ & $\begin{array}{c}\text { Sangat } \\
\text { Berat } \\
(\%)\end{array}$ \\
\hline ARS & 7 & 13 & 44 & 16 \\
& $(8,75)$ & $(16,25)$ & $(55,50)$ & $(20,00)$ \\
IRS & 9 & 24 & 35 & 12 \\
& $(11,25)$ & $(30,00)$ & $(43,75)$ & $(15,00)$
\end{tabular}

$\begin{array}{ccccc}\text { TLRS } & 15 & 27 & 27 & 11 \\ & (18,75) & (33,75) & (33,75) & (13,75) \\ \text { SRS } & 8 & 37 & 27 & 8 \\ & (10,00) & (46,25) & (33,75) & (10,00) \\ \text { DRS } & 27 & 26 & 20 & 7 \\ & (33,75) & (32,50) & (25,00) & (8,75)\end{array}$

$\begin{array}{lllll}\text { GARS } & 17 & 24 & 30 & 9\end{array}$

$$
(21,25) \quad(30,00) \quad(37,50) \quad(11,25)
$$

ARS $=$ Academic Related Stressors

IRS = Interpersonal \& Intrapersonal Related Stressors

TLRS $=$ Teaching \& Learning Related Stressors

SRS $=$ Social Related Stressors

DRS $=$ Drive \& Desire Related Stressors

GARS = Group Activities Related Stressors

Berdasarkan Tabel 2 dapat dilihat distribusi tingkat stres responden berdasarkan stressor. Didapatkan bahwa tingkat stres terkait akademik yang paling banyak dialami oleh responden adalah stres berat yaitu 44 responden $(55,50 \%)$, sedangkan untuk tingkat stres terkait akademis yang paling sedikit dialami mahasiswi adalah tingkat stres ringan yaitu 7 responden $(8,75 \%)$. Tingkat stres terkait hubungan intra dan personal yang paling 
banyak dialami oleh responden adalah stres berat yaitu 35 responden $(43,75 \%)$, sedangkan yang paling sedikit dialami mahasiswi adalah tingkat stres ringan yaitu 8 responden $(11,25 \%)$. Tingkat stres terkait kegiatan belajar mengajar yang paling banyak dialami oleh responden adalah stres berat dan stres sedang yaitu 27 responden $(33,75 \%)$, sedangkan untuk tingkat stres terkait kegiatan belajar mengajar yang paling sedikit dialami mahasiswi adalah tingkat stres ringan yaitu 11 responden $(13,75 \%)$. Tingkat stres terkait sosial yang paling banyak dialami oleh responden adalah stres sedang yaitu 37 responden $(46,25 \%)$, sedangkan untuk tingkat stres terkait sosial yang paling sedikit dialami mahasiswi adalah tingkat stres ringan dan stres sangat berat yaitu 8 responden $(10,00 \%)$. Tingkat stres terkait dorongan dan motivasi yang paling banyak dialami oleh responden adalah stres ringan yaitu 27 responden $(33,75 \%)$, sedangkan untuk tingkat stres terkait dorongan dan motivasi yang paling sedikit dialami mahasiswi adalah tingkat stres sangat berat yaitu 7 responden $(8,75 \%)$. Tingkat stres terkait aktivitas dalam suatu kelompok/grup yang paling banyak dialami oleh responden adalah stres berat yaitu 30 responden $(37,50 \%)$, sedangkan untuk tingkat stres aktivitas dalam suatu kelompok/grup yang paling sedikit dialami mahasiswi adalah tingkat stres ringan yaitu 9 responden $(11,25 \%)$.

\section{Distribusi Faktor Stres pada Responden}

Tabel 3. Distribusi Faktor Stres pada Responden

\begin{tabular}{ccc}
\hline Faktor Stres & $\begin{array}{c}\text { Jumlah } \\
\text { Responden }\end{array}$ & $\begin{array}{c}\text { Persen } \\
(\%)\end{array}$ \\
\hline Multiple Stresor & & \\
- 6 Stresor & 49 & 61,25 \\
- $\quad$ 5 Stresor & 13 & 16,25 \\
- 4 Stresor & 5 & 6,25 \\
- 3 Stresor & 4 & 5,00 \\
- 2 Stresor & 3 & 3,75 \\
Ringan/Normal & 6 & 7,50 \\
Total & 80 & 100 \\
\hline
\end{tabular}

Berdasarkan Tabel 3 dapat dilihat distribusi faktor stres pada responden. Didapatkan jumlah stresor yang paling banyak dimiliki oleh responden adalah 6 stresor yaitu 49 responden $(61,25 \%)$, sedangkan yang paling sedikit adalah 2 stresor yaitu 3 responden. Terdapat 6 responden yang memiliki skor $0.00-1.00$ pada perhitungan tingkatan stres berdasarkan faktor stres sehingga dianggap ringan/normal.

\section{Hubungan antara Stresor dengan Siklus Menstruasi}

Tabel 4. Hubungan antara Stresor dengan Siklus Menstruasi

\begin{tabular}{ccc}
\hline & Koefisien Korelasi & $\begin{array}{c}\boldsymbol{p} \\
\text { value }\end{array}$ \\
\hline ARS & 0,033 & 0,691 \\
IRS & $-0,048$ & 0,521 \\
TLRS & 0,042 & 0,579 \\
SRS & 0,138 & 0,084 \\
DRS & 0,083 & 0,319 \\
GARS & 0,041 & 0,620 \\
\hline
\end{tabular}

Berdasarkan Tabel 4 dapat dilihat hubungan antara stresor dengan siklus menstruasi. Melalui uji normalitas, didapat bahwa data penelitian ini tidak berdistribusi normal. Hubungan antara stresor dengan siklus menstruasi pada penelitian ini diidentifikasi dengan uji statistik Kendall's tau-c Correlation.

Tabel 4 menunjukkan nilai koefisien korelasi yang berbeda-beda untuk setiap stresor. Hal ini menunjukkan perbedaan arah dan kekuatan korelasi antara faktor stres dengan siklus menstruasi. Nilai significancy value atau $p$ value yang didapat menunjukkan tidak adanya hubungan yang signifikan antara setiap stresor dengan siklus menstruasi $(p>0,05)$.

\section{PEMBAHASAN}

\section{Karakteristik Responden}

Data pada penelitian ini diperoleh dari 80 orang mahasiswi Fakultas Kedokteran 
Universitas Universitas Sumatera Utara yang memenuhi kriteria inklusi dan tidak memenuhi kriteria eksklusi. Dari penelitian ini diperoleh data bahwa responden terbanyak berusia 21 tahun. Berdasarkan siklus menstruasi, responden dengan siklus menstruasi normal lebih banyak dibandingkan dengan siklus menstruasi tidak normal dengan jumlah 69 orang. Berdasarkan tingkat stres, tingkat stres yang terbanyak adalah tingkat stres berat yang berjumlah 38 orang.

\section{Gambaran Tingkat Stres berdasarkan Stressor}

Tingkat stres terkait akademis pada responden penelitian ini sebagian besar memiliki tingkat stres berat. Stresor terkait akademis merujuk kepada setiap kegiatan kampus, mahasiswa atau pendidikan yang dapat menyebabkan stres. Hal ini termasuk sistem ujian, metode penilaian, jadwal akademis, hingga kegiatan mahasiswa yang berhubungan dengan kegiatan akademis sehingga dapat menyebabkan nilai buruk saat ujian. ${ }^{[10]}$

Tingkat stres terkait hubungan intra dan personal pada responden penelitian ini sebagian besar memiliki tingkat stres berat. Stresor terkait hubungan intra dan personal merujuk kepada segala bentuk hubungan diantara dan pada mahasiswi yang dapat menyebabkan stres. Hal ini termasuk hubungan satu dengan yang lainnya, termasuk kurangnya motivasi untuk belajar dan konflik pribadi. ${ }^{[10]}$

Tingkat stres terkait akademis pada responden penelitian ini sebagian besar memiliki tingkat stres berat. Stresor terkait akademis merujuk kepada setiap kegiatan kampus, mahasiswa atau pendidikan yang dapat menyebabkan stres. Hal ini termasuk sistem ujian, metode penilaian, jadwal akademis, hingga kegiatan mahasiswa yang berhubungan dengan kegiatan akademis sehingga dapat menyebabkan nilai buruk saat ujian. ${ }^{[10]}$

Tingkat stres terkait kegiatan belajar mengajar pada responden penelitian ini sebagian besar memiliki tingkat stres sedang dan berat. Stresor terkait kegiatan belajar mengajar merujuk kepada setiap kegiatan yang berhubungan dengan sistem belajar mengajar yang dapat menyebabkan stres. Hal ini berhubungan dengan kelayakan tugas yang diberikan kepada mahasiswi, kemampuan dosen untuk mengajar, kualitas feedback yang diberikan dosen kepada mahasiswi, dan dukungan yang diberikan dosen kepada mahasiswi. ${ }^{[10]}$

Tingkat stres terkait sosial pada responden penelitian ini sebagian besar memiliki tingkat stres sedang. Stresor terkait sosial merujuk kepada segala bentuk hubungan komunitas dan sosial yang dapat menyebabkan stres. Hal ini termasuk waktu yang cukup untuk keluarga atau teman, bekerja di tempat umum, waktu pribadi, bekerja tanpa diganggu orang lain, dan menghadapi masalah pasien. ${ }^{10]}$

Tingkat stres terkait dorongan dan motivasi pada responden penelitian ini sebagian besar memiliki tingkat stres ringan. Stresor terkait dorongan dan motivasi merujuk kepada segala bentuk kemampuan internal dan eksternal yang memengaruhi sikap, emosi, pikiran, dan cara berperilaku dan dapat menyebabkan stres. Hal ini berhubungan dengan ketidakinginan untuk kuliah kedokteran yang dapat disebabkan oleh paksaan orang tua, menjadi tidak semangat setelah mengetahui realita sulitnya kedokteran, hingga mengikuti teman untuk kuliah kedokteran. ${ }^{[10]}$

Tingkat stres terkait aktivitas dalam suatu kelompok/grup pada responden penelitian ini sebagian besar memiliki tingkat stres berat. Stresor terkait aktivitas dalam suatu kelompok/grup merujuk kepada segala bentuk kegiatan dan interaksi kelompok/grup yang dapat menyebabkan stres. Hal ini termasuk partisipasi dalam diskusi kelompok/grup, presentasi, dan ekspektasi orang lain untuk berhasil. ${ }^{[10]}$

\section{Distribusi Faktor Stres pada Responden}

Responden yang memiliki skor $0.00-$ 1.00 dianggap memiliki tingkatan stres 
ringan/normal sehingga tidak memiliki faktor stres sedangkan responden yang memiliki skor >1.00 dianggap memiliki faktor yang menyebabkan stres pada responden. ${ }^{[10]}$

\section{Hubungan antara Stresor dengan Siklus Menstruasi}

Secara teori, stres dapat menyebabkan gangguan siklus menstruasi. Dalam pengaruhnya, stres melibatkan sistem neuroendokrinologi. [11] Pada saat stres terjadi pengaktifan hypothalamuspituitary-adrenal (HPA) aksis. Pengaktifan HPA aksis dapat mengakibatkan terjadinya sekresi corticotrophin releasing hormone $(\mathrm{CRH})$. Peningkatan $\mathrm{CRH}$ dapat menyebabkan meningkatnya kadar kortisol dalam plasma sehingga dapat mengurangi kadar LH pada fase folikular dan dapat menunda atau memblok peningkatan estradiol dan lonjakan gonadotropin. ${ }^{[12]}$

Pada Tabel 4 dapat dilihat bahwa tidak ditemukannya pengaruh antara stresor terkait akademis dengan siklus menstruasi. Belum ditemukan adanya penelitian yang menghubungkan stresor terkait akademis dengan siklus menstruasi tetapi terdapat suatu penelitian di Arab Saudi menemukan bahwa ada pengaruh stresor terkait akademis dengan nilai akademis. ${ }^{[13]}$

Ditemukan bahwa tidak adanya pengaruh antara stresor terkait hubungan intra dan personal dengan siklus menstruasi. Belum ditemukan adanya penelitian yang menghubungkan stresor terkait hubungan intra dan personal dengan siklus menstruasi tetapi terdapat suatu penelitian di Arab Saudi menemukan bahwa ada pengaruh stresor terkait hubungan intra dan personal dengan nilai akademis. $^{[13]}$

Ditemukan bahwa tidak adanya pengaruh antara stresor terkait kegiatan belajar mengajar dengan siklus menstruasi. Belum ditemukan adanya penelitian yang menghubungkan stresor terkait kegiatan belajar mengajar dengan siklus menstruasi tetapi terdapat suatu penelitian di Arab
Saudi menemukan bahwa tidak ada pengaruh stresor terkait kegiatan belajar mengajar dengan nilai akademis. ${ }^{[13]}$

Ditemukan bahwa tidak adanya pengaruh antara stresor terkait sosial dengan siklus menstruasi. Belum ditemukan adanya penelitian yang menghubungkan stresor terkait sosial dengan siklus menstruasi tetapi terdapat suatu penelitian di Arab Saudi menemukan bahwa tidak ada pengaruh stresor terkait dorongan dan motivasi dengan nilai sosial. $^{[13]}$

Ditemukan bahwa tidak adanya pengaruh antara stresor terkait dorongan dan motivasi dengan siklus menstruasi. Belum ditemukan adanya penelitian yang menghubungkan stresor terkait dorongan dan motivasi dengan siklus menstruasi tetapi terdapat suatu penelitian di Arab Saudi menemukan bahwa ada pengaruh stresor terkait dorongan dan motivasi dengan nilai akademis. ${ }^{[13]}$

Ditemukan bahwa tidak adanya pengaruh antara stresor terkait aktivitas dalam suatu kelompok/grup dengan siklus menstruasi. Belum ditemukan adanya penelitian yang menghubungkan stresor terkait aktivitas dalam suatu kelompok/grup dengan siklus menstruasi tetapi terdapat suatu penelitian di Arab Saudi menemukan bahwa ada pengaruh stresor terkait aktivitas dalam suatu kelompok/grup dengan nilai akademis. ${ }^{[13]}$

\section{KESIMPULAN}

Tidak ditemukan pengaruh yang signifikan antara faktor stres dengan siklus menstruasi pada mahasiswi Fakultas Kedokteran Universitas Sumatera Utara.

\section{SARAN}

Peneliti menyarankan pada peneliti selanjutnya untuk mempertimbangkan berbagai metode yang dapat digunakan selain metode yang digunakan dalam penelitian ini. 
DAFTAR PUSTAKA

[1] Priscilla V, Ningrum DCR, Fajria L. Perbedaan Pengaruh Teknik Relaksasi Nafas Dalam Dan Kompres Hangat Dalam Menurunkan Dismenore Pada Remaja SMA Negeri 3 Padang. NERS J Keperawatan. 2012;10(2):187.

[2] Yudita NA, Yanis A, Iryani D. Hubungan antara Stres dengan Pola Siklus Menstruasi Mahasiswi Fakultas Kedokteran Universitas Andalas. J Kesehat Andalas. 2017;6(2):299.

[3] Toduho S, Kundre R, Malara R. Hubungan Stres Psikologis Dengan Siklus Menstruasi Pada Siswi Kelas 1 Di Sma Negeri 3 Tidore Kepulauan. J Keperawatan UNSRAT. 2014;2(2):107750.

[4] Sutjiato M, Tucunan GDK. Hubungan Faktor Internal dan Eksternal dengan Tingkat Stress pada Mahasiswa Fakultas Kedokteran Universitas Sam Ratulangi Manado. Jikmu. 2015;5(1):30-42.

[5] Kesehatan J. Jurnal Kesehatan Published By Poltekkes Ternate , 12 ( 2 ), 2019 , Pages 15 - 22. 2019;12(2):15-22.

[6] Noviana E. Pengaruh Tingkat Stres dengan Menstruasi Terhadap Wanita Usia Reproduktif pada Mahasiswi Kedokteran FK USU. 2018;62. Available from: http://repositori.usu.ac.id

[7] Saerang A, Suparman E, Lengkong RA. Hubungan Antara Stres Dengan Pola Menstruasi Pada Mahasiswi Fakultas Kedokteran Universitas Sam Ratulangi Manado Angkatan 2010. e-CliniC. 2014;2(3).

[8] Montero-López E, Santos-Ruiz A, García-Ríos MC, RodríguezBlázquez M, Rogers HL, PeraltaRamírez MI. The relationship between the menstrual cycle and cortisol secretion: Daily and stressinvoked cortisol patterns. Int $\mathrm{J}$ Psychophysiol.

2018;131(March):67-72.

[9] Rad M, Torkmannejad Sabzevary M, Mohebbi Dehnavi Z. Association Between Menstrual Disorders and Obesity-Related Anthropometric Indices in Female High School Students: A Cross-Sectional Study. Int J Sch Heal. 2018;5(2).

[10] Yusoff MSB, Rahim AFA. The Medical Student Stressor Questionnaire ( MSSQ ) Manual An explanatory guide on stress and stressors in medical study to help you. 2014;(February 2010).

[11] Tombokan KC, Pangemanan DHC, Engka JNA. Hubungan antara stres dan pola siklus menstruasi pada mahasiswa Kepaniteraan Klinik Madya (co-assistant) di RSUP Prof. Dr. R. D. Kandou Manado. J eBiomedik. 2017;5(1).

[12] Breen KM, Billings HJ, Wagenmaker ER, Wessinger EW, Karsch FJ. Endocrine basis for disruptive effects of cortisol on preovulatory events. Endocrinology. 2005;146(4):2107-15.

[13] Habeeb KA. Prevalence of Stressors among Female Medical Students. J Taibah Univ Med Sci [Internet]. 2010;5(2):110-9. Available from: $\underline{10.1016 / \mathrm{S} 1658-3612(10) 70140-2}$ 